REVIEW ARTICLE

\title{
Partially Hydrolyzed Formulas: Do They Play Any Role in the Pre- vention of Atopic Dermatitis?
}

\author{
Carlos Alberto Sánchez Salguero ${ }^{1^{*}}$ and Alvaro Isidro Sánchez Chacon ${ }^{2}$ \\ ${ }^{1}$ Head of Pediatric Allergy and Pneumology Section and Professor of Pediatric School of Medicine, University \\ Hospital Puerto Real, Spain
}

${ }^{2}$ Pediatric Department, University Hospital Puerto Real, Spain

*Corresponding author: Carlos Alberto Sánchez Salguero, Head of Pediatric Allergy and Pneumology Section and Professor of Pediatric School of Medicine, University Hospital Puerto Real, Spain, E-mail: libraygeminis@hotmail.com

Atopic Dermatitis (AD) is a chronic, recurrent, inflammatory skin disease with an immune mechanism. It appears in genetically predisposed children in whom hypersensitivity reactions to varied antigens (food, neumoalergens, bacterial proteins), release inflammatory mediators that lead to the development of eczematous skin lesions. It diagnosis is eminently clinical being the criteria of Hanifin-Rajka of 1980 the most used [1,2].

It is considered one of the clinical entities linked to the so-called Allergic March and a disease of childhood that in $60 \%$ of patients starts in the first year of life, in $85 \%$ in the first 5 years and only in $10 \%$ after 7 -yearsold, although both their prevalence and severity tend to decrease with age [1]. Approximately $12 \%$ of the first visits to the Pediatric Allergy consultations in Spain correspond to cases of $A D$, accompanied by a $40 \%$ sensitization to neumoallergens or foods (most frequently the cow's milk protein) [3].

In recent decades, an increase in the number of cases of $A D$ has been described, especially in Western countries. In the United States figures are cited of up to $10-20 \%$, while in our country it is estimated that there is a prevalence of around 4.1-7.6\% [4].

In order to try to contain this trend, several strategies have been designed in the field of nutrition that have gone from focusing on avoiding exposure to the allergens most commonly involved in allergic diseases through diets in the pregnant and nursing mother, the use of highly hydrolyzed formulas in the first months of life and the delay in the introduction of some foods to a more active form of prevention based on immunomodulation and in trying to promote the induction of tolerance through eating patterns in the first months of life, a key period in the development of tolerance phenomena. This is a strategy that is considered today more attractive than the exclusion diet because it is relatively simple, it is not expensive and the risk of adverse consequences from the nutritional point of view is low. It includes the use of partially hydrolyzed formulas, vitamins, omega- 3 fatty acids, prebiotics and probiotics as the most studied measures [5-7].

This article focuses exclusively on the role of a Partially Hydrolyzed serum Formula (PHFs) in the first months of life, as a preventive measure for the subsequent development of a DA, without considering the possible effect that the other dietary measures proposed may have on the prophylaxis of allergic diseases in general.

\section{Partially Hydrolyzed Formulas or Low Degree of Hydrolysis}

The main characteristic of these type of formulas is that its protein content has been subjected to processes of heating and enzymatic hydrolysis with the aim of reducing its allergenicity. Unlike extended or high-grade hydrolysates, partial hydrolysates are contraindicated in children with a diagnosis of cow's milk proteins allergy since they contain peptides whose molecular weight ranges from 4,000-10,0000 daltons on average to a high likelihood may trigger an allergic reaction in sensitized children [8]. They are designed for the consumption of healthy infants, being less expensive and more palat-

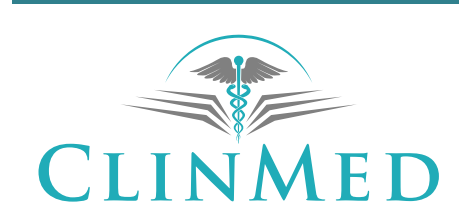

INTERNATIONAL LIBRARY
Citation: Salguero CAS, Chacon AIS (2018) Partially Hydrolyzed Formulas: Do They Play Any Role in the Prevention of Atopic Dermatitis?. Int J Aller Medications 4:028. doi.org/10.23937/2572-3308.1510028 Accepted: June 23, 2018: Published: June 25, 2018

Copyright: (C) 2018 Salguero CAS, et al. This is an open-access article distributed under the terms of the Creative Commons Attribution License, which permits unrestricted use, distribution, and reproduction in any medium, provided the original author and source are credited. 
Table 1: Studies of high-moderate quality on the use of partially hydrolyzed formulas for the prevention of atopic dermatitis.

\begin{tabular}{|c|c|c|c|c|}
\hline Reference & Design of study & Population study & Breastfeeding & Supplementary feeding \\
\hline Vandenplas $[18,19]$ & $\begin{array}{l}\text { Randomized } \\
\text { Double-blind }\end{array}$ & $\begin{array}{l}2 \text { AF } \\
- \text { PHWP n } 28 \\
- \text { CF n } 30\end{array}$ & No & $\begin{array}{l}0-4 \mathrm{~m} \text { : formula } \\
4 \mathrm{~m}: \text { grated apple } \\
\text { > } 6 \mathrm{~m} \text { : diversification without } \\
\text { limitations }\end{array}$ \\
\hline Marini [21] & $\begin{array}{l}\text { Randomized } \\
\text { Double-blind }\end{array}$ & $\begin{array}{l}2 \text { AF } \\
- \text { PHWP n } 41 \\
- \text { CF n } 43\end{array}$ & Yes & $\begin{array}{l}0-5 \mathrm{~m}: \mathrm{BF} \pm \text { formula } \\
\text { 5-12 m: hypoallergenic foods } \\
>12 \mathrm{~m} \text { : unrestricted diet }\end{array}$ \\
\hline Chan [23] & Randomized & $\begin{array}{l}1 \text { AF } \\
- \text { PHWP n } 53 \\
- \text { CF n } 57\end{array}$ & No & $\begin{array}{l}0-4 \mathrm{~m} \text { : formula } \\
>4 \mathrm{~m} \text { : diversification without } \\
\text { limitations }\end{array}$ \\
\hline Von Berg [24] & $\begin{array}{l}\text { Randomized } \\
\text { Double-blind }\end{array}$ & $\begin{array}{l}1 \text { AF } \\
- \text { PHWP n } 241 \\
\text { - CF n } 256\end{array}$ & Yes & $\begin{array}{l}0-4 \mathrm{~m} \text { : formula } \\
>4 \mathrm{~m} \text { : diversification without } \\
\text { limitations }\end{array}$ \\
\hline
\end{tabular}

AF: First-Degree Family History of Atopy; PHWP: Partially Hydrolyzed Whey Protein; CF: Conventional Formula; BF: BreastFeeding.

able in taste than extensive hydrolysates. Initially marketed for the prevention of food allergy, over time they appear to have focused more on the treatment of minor digestive problems such as infant colic, gastroesophageal constipation or reflux and for which, accompanying the partial hydrolysis (decrease in the amount of lactose, palmitic acid in beta position, addition of a thickener, prebiotics and/or probiotics), although there are no serious scientific studies demonstrating the efficacy of these modifications in these diseases [9].

In relation to the type of protein, the majority only contains serum proteins, of better flavor than the caseins and that favor a gastric emptying faster. There is a belief that, because they are partially hydrolyzed, they can be digested better, although in reality there is no scientific evidence to prove it or the absorption and use of the nitrogen component is greater.

\section{Frequently Asked Questions Regarding the Use of Partially Hydrolyzed Formulas}

It should not be forgotten that the best option in infant feeding is BreastFeeding (BF). Only when it is not possible to carry it out exclusively, the question arises as to which formula has the best short-term and long-term effects in the area of allergic disease prevention and $A D$ in particular.

\section{To what extent are the results we have reliable?}

The role of partial hydrolyzed formulas in the prevention of allergic diseases and $A D$ has been studied by different authors although the analysis of the data obtained in these studies is not easy because many of them lack a good methodology. Several of them establish the diagnosis of $A D$ without the need for the physical examination of the researcher and only with the description of the symptoms by the family through the form or the diagnosis by another non-doctor belonging to the study [10-14]. Others do not specify in detail the composition of the formula used, do not refer to adherence and tolerance data or do not take into account exposure to other factors that may influence the development of $A D$ such as exposure tobacco smoke or diversification of the rest of the diet $[15,16]$. One of them initially compares the use of a Conventional Formula (CF), soy formula and later when it already includes 97 patients, adds as third formula to study the PHFs [14] and even three studies carried out by the same group, and whose results were initially based some revisions and recommendations, have finally been rejected because their results cannot be validated in a later revision [17].

That is why most reviews and meta-analyzes highlight the difficulty in obtaining clear conclusions and are based especially on the data obtained from 4 studies considered of higher quality and that have a study population and/or a similar design (Table 1).

The first is a Belgian study $[18,19]$ which shows a lower incidence of $A D$ at 3 years in PHFs-fed at-risk infants compared to those with $\mathrm{CF}$, although it does not statistically compare both groups. Szajewska and Horvath subsequently performed it without finding significant differences in terms of Relative Risk (RR) with a $95 \%$ confidence interval $(\mathrm{Cl})$ of $95 \%$ per year (RR 0.46, $\mathrm{Cl} 0.13-1.60$ ) or 36 months (RR 1.07, Cl 0.43-2.67) [20].

- Marini performs an intervention study in Italy with a follow-up up to 3 years of 279 at-risk infants who cannot maintain exclusive $\mathrm{BF}$ in the first 5 months [21]. Childs: 48 received PHFs, 47 received CF, 32 mixed with PHFs and 28 mixed with FC. Subsequently, all receive a hypoallergenic diet until the year of age along with environmental preventive measures. Although the number of cases of $A D$ up to 3 years is lower in those who receive PHFs compared to those who receive hydrolyzed formula, the cumulative incidence of $A D$ among the different groups, calculated in a subsequent analysis, does not show significant differences (per year: RR 0.48, $\mathrm{Cl} 0.13-1.78$ and at 3 years $\mathrm{RR} 0.42, \mathrm{Cl} 0.14-1.26$ ) [22].

- Chan published in 2002 a study carried out in Singapore with 110 children, all fed from the outset with 
artificial feeding, of whom 53 received PHFs and 57 exclusively CF during the first 4 months [23]. The type of feeding that they carry out in this period of intervention is known by the parents but not by the physicians who follow up, passing from the 4 months to the introduction of the complementary feeding without restrictions except by the type of formula received. The follow-up period lasts up to 30 months and the results obtained are evaluated taking into account several factors that can potentially cause confusion (socioeconomic level, family environment, presence of pets, use of air conditioning). However other factors that may also influence the development and evolution of $A D$ such as the introduction of foods are not specified or valued.

The data reflect a significant reduction in the risk of $A D$ throughout the first two years in the group receiving PHFs and a lower incidence accumulated in the follow-up period (odds ratio $0.20, p 0.011$ at 3 months' odds Ratio 0.37, p 0.019 at 2 years) without observing differences in the incidence of other atopic manifestations (rhinitis and urticarial).

- Lastly, the GINI (German Infant Nutritional Intervention) study is a project designed and carried out in Germany to test the relative efficacy of three hydrolyzed formulas against CF in the field of prevention of allergic manifestations in children with risk [24].

It is a very important study, not only for its design but also for the large study population of 2,252 infants who, in the case of not being able to maintain exclusive $\mathrm{LM}$, are assigned by randomization to take during the first 4 months of life: PHFs, CF, Extensive Casein Hydrolysate (ECH) or an Extensive Hydrolysate of serum proteins (EHsp).

As in Marini's study, it is not exclusion criteria to be with breastfeeding. In fact, around $42 \%$ of the infants received it exclusively in the first 4 months, with the rest (1249) actually forming the population to be studied. However, the quantity and duration of BF are not specified before starting artificial formula in the different groups, although complementary feeding takes place in a controlled way, starting at 4-6 months and avoiding the introduction of cow's milk, egg, fish, soy, tomato and citrus in the first year.

The incidence of AD per year in the EHsp-consuming group is lower compared to $\mathrm{CF}$ when adjusted with factors also involved in the development of $A D$ such as sex, exposure to tobacco, and the existence of $A D$ in the background (odds ratio $0.56 \mathrm{Cl} 0.32-0.99$ ). Both $\mathrm{ECH}$ and EHsp reduce the incidence of $A D$ by more than $50 \%$ to one year, especially in those with no family history of $A D$, postulating the possibility that the preventive effect of nutritional intervention is more pronounced in children with no load important genetics. In the presence of a family history of $A D$, only HCF would reduce the risk of
CF. This trend remains at 3 years, when the cumulative incidence of $A D$ in the group receiving EHps continues to be lower than the one that receives $\mathrm{FC}$, and also the significance persists when it is adjusted again with the aforementioned variables (odds ratio $0.60 \mathrm{Cl} 0.37-0.97$ ) [25].

Subsequent publications show that the preventive effect of $\mathrm{HF}$ and EHsp on $A D$ appears to be prolonged up to 10 years, with those concerning the 15 years of evolution still pending. These data should be analyzed more carefully because they refer to a high dropout rate (64.4\%) and differ in some details from the initial design of the study up to 3 years, so that from this age onwards information is obtained through a survey of parents, with the possible bias that this may entail $[26,27]$. Although it does not provide data on the type of $A D$ that is prevented in relation to intensity (mild, moderate or severe), it does provide information on the type in relation to the age of onset and its later duration, such that it reveals differences between groups in cases of persistent $A D$ (onset of symptoms in the first 2 years, with persistence up to 5-6 years of age), being lower in those receiving ECH or EHsp. There are no variations in the other $\mathrm{DA}$ types, i.e. early-onset $A D$ (below 2 years), late-onset $A D$ (2-6 years), persistent $A D$ up to 3-4 years and intermittent $A D$, in the evolution seems to be independent of the type of formula used [27].

The first reviews on the role of hydrolyzed formulas in the prevention of allergic diseases conclude that the use of hydrolysates (long and partial) up to 4-6 months are appropriate alternatives to $\mathrm{BF}$ for the prevention of allergic diseases in at-risk infants, emphasizing that this preventive effect is more noticeable in $A D[20,22,28,29]$ One of them is a comparison between extensive and partial hydrolysates without appreciating benefits with the use of the former with respect to the latter except in the cumulative incidence of allergic diseases between 0-36 months [20].

Nonetheless, in spite of all the above, subsequent reviews with more rigorous criteria in the studies subject to analysis, offer a much more cautious and less categorical conclusion that highlights the limited evidence that exists on this subject that is almost exclusively limited to results of the 4 studies referred to above as being of higher methodological quality [30]. In 2010, Alexander encompasses data on the cumulative incidence of $A D$ up to 36 months of age, based on the fact that they all have similar design, diagnostic criteria and follow-up (are randomized, in a population at risk, include as objective to evaluate the incidence of $A D$ with rigorous diagnostic criteria and control the BF factor, either establishing it as an exclusion criterion or including it in the subsequent statistical analysis as a possible confounding factor). As a result of this joint assessment, there are statistically significant differences in the cumulative incidence of $A D$ as early as 6 months of age (26 cases of 
384 infants in the CF group versus 7 of 365 in the PHFs group) 12 months (72 of 384 vs. 35 of 365), 24 months (78 of 383 versus 41 of 364) and 36 months (96 of 370 versus 60 of 350) [31].

Following this line of caution, the US Food and Drug Administration (FDA) performs an excellent review focused exclusively on analyzing published scientific evidence on the use of PHFs in the prevention of $A D$ up to 3 years of age in infants of risk. It concludes literally: "There is limited scientific evidence that for healthy infants who do not receive exclusive $\mathrm{BF}$ and who have a family history of atopy, feeding with PHFs up to 4 months of age instead of CF can reduce risk of development of $A D$ throughout the first year of life and up to 3 years of age", reiterating the need to obtain more data through broad studies, high methodological quality that can contrast and validate those obtained in the GINI study [32].

\section{Is the profit obtained from one hydrolysate to anoth- er from a different commercial brand, whose hydro- lysis and composition are different, extrapolated?}

Much had been discussed about what would be the main mechanism of action of the PHFs. Unlike extensive hydrolysates, they do not cause a decrease in sensitization, so avoiding antigen exposure is not a factor involved in its mechanism of action. As an alternative, it is speculated that partial hydrolysis may allow certain peptides with immunomodulatory properties, which favor immunological tolerance phenomena or antimicrobial properties to remain intact. In this case, the method used to obtain the hydrolysis would be of great importance since it would be determinant in the characteristics of the resulting peptides, beyond their molecular weight. In addition, other components of the formulas, oligosaccharides, omega- 3 fatty acids and some probiotic strains may also have immunomodulatory properties and may enhance the preventive effect to a greater or lesser extent. This is why the EAACl in its recommendations emphasizes that the evaluation of the efficacy of the formulas should be based not so much on the type of protein they contain (caseins or serum proteins), so to trademarks [33].

\section{To what extent is it worth the possible preventive effect achieved on AD?}

In all the studies there is a common constant and is that the use of PHFs has no preventive effects on asthma, allergic rhinitis and sensitization to allergens. Does the use of PHFs justify the potential preventive effect on $A D$ ? The answer must be considered taking into account that the benefits will be variable according to the region, the $B F$ rate, the prevalence of $A D$ and the severity of the same.

An estimate of the economic impact that the use of an PHFs compared to a CF would offer in 5 European countries (Denmark, Germany, Switzerland, France and
Spain) had been published. It takes as a basis the prevention estimates published so far. It includes variables on loss of time and income for families, use of resources of the Health System and the costs associated with the treatment of $A D$. The results related to cost-benefit in our country have a positive effect in all of them [34].

\section{Is the use of hydrolysates safe in a healthy popu- lation?}

It is speculated by some authors that extensive hydrolysates could cause a lack of induction of tolerance and in the long term cause an increase in the risk of developing allergy. There is, however, no work to date that has reported negative effects with the use of hydrolysates in healthy population, neither from the nutritional point of view (parameter specially controlled in the GINI study) nor from the evolutionary point of view although there is no reduction in the prevalence of asth$\mathrm{ma}$, nor is there a statistically significant increase in the same in the groups that use PHFs compared to those who use CF [35].

\section{Are the current recommendations on food in the first year of life for the prevention of allergic dis- eases appropriate?}

Practically there are only two preventive measures that unanimously all the Scientific Societies recommend. One is to avoid exposure to tobacco smoke in both gestation and lactation and to maintain the exclusive BF in the first months of life [36]. Considered the most suitable form of feeding of any healthy infant, doubts arise when it is not possible to maintain it: what is the best alternative? what kind of formula? for how long? in what type of children? What other preventive measures?

Although the different Scientific Societies initially made quite different recommendations, today, after the last published reviews, they are very similar $[33,37,38]$ (Table 2).

Focusing only on the use of PHFs, all Scientific Societies maintain that there is some evidence that their use in the first 4-6 months of life may have a mediumand long-term preventive effect on $A D$, but there is not enough data yet to recommend the use of partial hydrolysates in the prevention of it in a systematic way.

We must not forget, finally, that all these preventive measures are focused exclusively on the so-called risk population defined only on the basis of family history, despite the fact that there is a significant percentage of children who develop allergy and AD without having a history of atopy. Would the percentage of cases decrease even more if preventive measures were taken in the general population? Unfortunately, as has been a constant in this subject, there are no studies designed correctly that can answer this question and therefore we still do not know if different results will be obtained with the application of broader prevention strategies. 
Table 2: Current recommendations for feeding during the first year of life for prevention of allergic diseases.

\begin{tabular}{|c|c|c|}
\hline & ESPGHAN/EAACI $[33,37]$ & AAP [38] \\
\hline Definition of infant high risk & A first-degree relative with atopy & Two first-degree relative with atopy \\
\hline Exclusion diet pregnancy foods & $\begin{array}{l}\text { Not recommended } \\
\text { There is no evidence nutritional risk benefit }\end{array}$ & $\begin{array}{l}\text { 2000: Not recommended, with the } \\
\text { possible exception Peanut exclusion } \\
\text { 2008: Not recommended } \\
\text { There is no evidence to support the } \\
\text { exclusion of } \\
\text { Peanut diet }\end{array}$ \\
\hline The exclusion diet mother during LM & $\begin{array}{l}\text { Not recommended } \\
\text { There is no evidence nutritional risk benefit }\end{array}$ & $\begin{array}{l}\text { 2000: Diet peanut exclusion nuts. } \\
\text { Consider exclusion of egg, milk beef and } \\
\text { fish. 2008: Not recommended }\end{array}$ \\
\hline LM exclusive & Recommended for $4-6$ months & $\begin{array}{l}\text { 2000: } 6 \text { months } \\
\text { 2008: Suitable for } 4-6 \text { months }\end{array}$ \\
\hline Use of hydrolysates & $\begin{array}{l}\text { Reduced allergenicity formulas } \\
\text { (extensive hydrolyzed) to } 4-6 \\
\text { months as a substitute/supplement } \\
\text { LM }\end{array}$ & $\begin{array}{l}\text { Hydrolysed or otherwise extensive } \\
\text { hydrolysates partial to } 4-6 \text { months } \\
\text { substitute/supplement LM. } \\
\text { There are only some evidence that the } \\
\text { use of PHWP decreases/DA delays. }\end{array}$ \\
\hline Using formulas soy & Not recommended & Not recommended \\
\hline Beginning of diversification feed & Not before 4-6 months & $\begin{array}{l}\text { 2000: From } 6 \text { months } \\
\text { 2008: not before } 4-6 \text { months }\end{array}$ \\
\hline Delayed introduction food & $\begin{array}{l}\text { Not recommended } \\
\text { There is no evidence that modifications } \\
\text { dietary beyond } 6 \text { months have preventive } \\
\text { effect }\end{array}$ & $\begin{array}{l}\text { 2000: a year cow's milk, egg at } 2 \text { years, } \\
\text { peanuts, nuts and fish at } 3 \text { years } \\
\text { 2008: There is no evidence supporting } \\
\text { the delay in the introduction of egg, fish } \\
\text { and food containing peanut protein }\end{array}$ \\
\hline
\end{tabular}

ESPGHAN: European Society of Pediatric Gastroenterology and Nutrition; EAACI: European Academy of Allergology and Clinical Immunology; AAP: American Academy of Pediatrics.

\section{References}

1. Martin Mateos MA (2011) Tratado de Alergología Pediátrica. In: Martorell A, Febrer MI, Rodríguez M, Dermatosis crónicas en Pediatría. Dermatitis atópica. Dermatitis de contacto. (2 $2^{\text {nd }}$ edn), Madrid Ergon 179-198.

2. Hanifin JM, Rajka G (1980) Diagnostic features of atopic dermatitis. Acta Derm Venereol 92: 44-47.

3. Nieto A, Mazon A, Martín-Mateos MA, Plaza AM, Garde $\mathrm{J}$, et al. (2011) Pediatric allergy and immunology in Spain. Pediatr Allergy Immunol 22: 742-750.

4. Suárez-Varela MM, Alvarez LG, Kogan MD, Ferreira JC, Martínez Gimeno A, et al. (2010) Diet and prevalence of Atopic Eczema in 6 to 7-year-old Schoolchildren in Spain: ISAAC Phase III. J Investig Allergol Clin Immunol 20: 469475.

5. Chehade M, Mayer LI (2008) Oral tolerance and its relation to food hypersensitivities. J Allergy Clin Immunol 115: 3-12.

6. Heine RG, Tang MLK (2008) Dietary approaches to the prevention of food allergy. Curr Opin Clin Nutr Metab Care 11: 320-328.

7. Grimshaw KE, Allen K, Edwards CA, Beyer K, Boulay A, et al. (2009) Infant feeding and allergy prevention: A review of current knowledge and recommendations. A EuroPrevall state of the art paper. Allergy 64: 1407-1416.

8. Host A, Halken S (2004) Hypoallergenic fórmulas- when, to whom, and how long: After more than 15 years we know the right indication. Allergy 59: 45-52.

9. Berseth CL, Mitmesser SH, Ziegler EE, Marunycz JD, Van- derhoof J (2009) Tolerance of a standard intact protein formula versus a partially hydrolyzed formula in healthy, term infants. Nutrition J 8: 27.

10. ExI BM, Deland U, Secretin MC, Preysch U, Wall M, et al. (2000) Improved general health status in a selected infant population following an allergen reduced dietary intervention programme: The Zuffstudy- Programme. Part II: Infant growth and health status to age 6 months. Eur J Nutr 39: 145-156.

11. Vandenplas Y, Deneyer M, Sacre L, Loeb H (1988) Preliminary data on a field study with a new hypoallergenic formula. Eur J Pediatr 148: 274-277.

12. D’Agata A, Betta P, Sciacca P, Morano C, Praticó G, et al. (1996) Role of dietary prevention in newborns at risk for atopy. Results of a follow-up study. Pediatr Med Chir 18: 469-472.

13. Willems R, Duchateau J, Magrez P, Denis R, Casimir G (1993) Influence of hypoallergenic milk formula on the incidence of early allergic manifestations in infants predisposed to atopic diseases. Ann Allergy 71: 147-150.

14. Lowe AJ, Hosking CS, Bennett CM, Allen KJ, Aselrad C, et al. (2011) Effect of a partially hydrolyzed whey infant formula at weaning on risk of allergic disease in high-risk children: A randomized controlled trial. J Allergy Clin Immunol 128: $360-365$.

15. Chirico G, Gasparoni A, Ciardelli L, De Amici M, Colombo A, et al. (1997) Immunogenicity and antigenicity of a partially hydrolyzed cow's milk formula. Allergy 52: 82-88.

16. De Seta L, Siani P, Cirillo G, Di Gruttola M, Cimaduomo $\mathrm{L}$, et al. (1994) The prevention of allergic diseases with a 
hypoallergenic formula: A follow-up at 24 months. The preliminary results. Pediatr Med Chir 16: 251-254.

17. Chandra RK (1997) Five-year follow-up of high-risk infants with family history of allergy who were exclusively breastfed or fed partial whey hydrolysate, soy and conventional cow's milk fórmulas. J Pediatr Gastroenterol Nutr 24: 380388.

18. Vandenplas Y, Hauser B, Van den Borre C, Sacre L, Dab I (1992) Effect of a whey hydrolysate prophylaxis of atopic disease. Ann Allergy 68: 419-424.

19. Vandenplas Y, Hauser B, Van den Borre C, Clybouw C, Mahler T, et al. (1995) The long-term effect of a partial whey hydrolysate formula on the prophylaxis of atopic disease. Eur J Pediatr 154: 488-494.

20. Szajewska H, Horvath A (2010) Meta-analysis of the evidence for a partially hydrolyzed $100 \%$ whey formula for the prevention of atopic diseases. Curr Med Res Opinion 26: 423-437.

21. Marini A, Agostoni M, Motta G, Mosca F (1996) Effects of a dietary and environmental prevention programme on the incidence of allergic symptoms in high atopic risk infants: Three years' follow-up. Acta Paediatr Suppl 414: 1-21.

22. Alexander DD, Cabana MD (2010) Partially hydrolyzed $100 \%$ whey protein infant formula and reduced risk of atopic dermatitis: A meta-analysis. J Pediatr Gastroenterol Nutr 50: 422-430.

23. Chan YH, Shek LP, Aw M, Quak SH, Lee BW (2002) Use of hypoallergenic formula in the prevention of atopic disease among Asian children. J Paediatr Child Health 38: 84-88.

24. Von Berg A, Koletzko S, Grübl A, Filipiak-Pittroff B, Wichmann HE, et al. (2003) The effect of hydrolyzed cow's milk formula for allergy prevention in the first year of life: The German Infant Nutritional Intervention Study, a randomized double-blind trial. J Allergy Clin Immunol 111: 533-540.

25. Von Berg A, Koletzko S, Filipiak-Pittroff B, Laubereau B, Grübl A, et al. (2007) Certain hydrolyzed formulas reduce the incidence of atopic dermatitis but not that of asthma: Three-year results of the German Infant Nutritional Intervention Study. J Allergy Clin Immunol 119: 718-725.

26. Von Berg A, Filipiak-Pittroff B, Kramer U, Link E, Bolrath C, et al. (2008) Preventive effect Office hydrolyzed infant formulas persists until age 6 years: Long-term results from The German Infant Nutritional Intervention (GINI). J Allergy Clin Immunol 121: 1442-1447.

27. Von Berg A, Filipiak-Pittroff B, Kramer U, Hoffmann B, Link E, et al. (2013) Allergies in high-risk schoolchildren after early intervention with cow's milk protein hydrolysates: 10 years results from the German Infant Nutritional Intervention (GINI) study. J Allergy Clin Immunol 131: 1565-1573.
28. Hays T, Wood RA (2005) A systematic review of the role of hydrolyzed infant formulas in allergy prevention. Arch Pediatr Adolesc Med 159: 810-816.

29. Osborn DA, Sinn J (2006) Formulas containing hydrolyzed protein for prevention of allergy and food intolerance in infants. Cochrane Database Syst Rev 18: CD003664.

30. Osborn DA, Sinn J (2009) Formulas containing hydrolyzed protein for prevention of allergy and food intolerance in infants (Review). Cochrane Database of Systematic Reviews 2006: CD003664.

31. Alexander DD, Schmitt DF, Tran NL, Barraj LM, Cushing CA (2010) Partially hydrolyzed $100 \%$ whey protein infant formula and atopic dermatitis risk reduction: A systematic review of the literature. Nutr Rev 68: 232-245.

32. Chung CS, Yamini S, Trumbo PR (2012) FDA'Health Claim Review: Whey-protein partially hydrolyzed infant formula and atopic dermatitis. Pediatrics 130: e408-e414.

33. Host A, Halken S, Muraro A, Dreborg S, Niggemann B, et al. (2008) Dietary prevention of allergic diseases in infants and small children. Pediatr Allergy Immunol 19: 1-4.

34. Spieldenner J, Belli D, Dupont $C$, Haschkea F, Iskedjian M, et al. (2011) Hydrolyzed $100 \%$ whey-based infant formula and the prevention of atopic dermatitis: Comparative pharmacoeconomic analyses. Ann Nutr Metab 59: 44-52.

35. Rzehak P, Sausenthaler S, Koletzko S, Reinhardt D, Von Berg A, et al. (2011) Long-term effects of hydrolyzed protein infant formulas on growth-extended follow-up to $10 \mathrm{y}$ of age: Results from the German Infant Nutritional Intervention (GINI) study. Am J Clin Nutr 94: 1803S-1807S.

36. Yang YW, Tsai CL, Lu CY (2009) Exclusive breastfeeding and incident atopic dermatitis in childhood: A systematic review and meta-analysis of prospective cohort studies. $\mathrm{Br} \mathrm{J}$ Dermatol 161: 373-383.

37. Høst A, Koletzko B, Dreborg S, Muraro A, Wahn U, et al. (1999) Dietary products used in infants for treatment and prevention of food allergy. Joint statement of the European Society for Pediatric Allergology and Clinical Immunology (ESPACI) Committee on Hypoallergenic Formulas and European Society for Pediatric Gastroenterology, Hepatology and Nutrition (ESPGHAN) Committee on Nutrition. Arch Dis Child 81: 80-84.

38. Greer FR, Sicherer SH, Burks W, Committee on Nutrition, Section on Allergy and Immunology (2008) Effects of early nutritional interventions on the development of atopic disease in infants and children: The role of maternal dietary restriction, breastfeeding, timing of introduction of complementary foods, and hydrolyzed formulas. Pediatrics 121: 183-191. 